\title{
Review
}

\section{Targeting glucose metabolism for healthy aging}

\author{
Rachel A. Brewer ${ }^{\mathrm{a}}$, Victoria K. Gibbs ${ }^{\mathrm{a}, \mathrm{b}, \mathrm{c}, \mathrm{d}}$ and Daniel L. Smith Jr. ${ }^{\mathrm{a}, \mathrm{b}, \mathrm{c}, \mathrm{d}, *}$ \\ ${ }^{a}$ Department of Nutrition Sciences, University of Alabama at Birmingham, Birmingham, AL, USA \\ ${ }^{\mathrm{b}}$ Nutrition Obesity Research Center, Department of Nutrition Sciences, University of Alabama at Birmingham, \\ Birmingham, AL, USA \\ ${ }^{\mathrm{c}}$ Comprehensive Center for Healthy Aging, University of Alabama at Birmingham, Birmingham, AL, USA \\ ${ }^{\mathrm{d}}$ Nathan Shock Center of Excellence in the Biology of Aging, University of Alabama at Birmingham, Birmingham, \\ $A L, U S A$
}

\begin{abstract}
Advancing age is the greatest single risk factor for numerous chronic diseases. Thus, the ability to target the aging process can facilitate improved healthspan and potentially lifespan. Lack of adequate glucoregulatory control remains a recurrent theme accompanying aging and chronic disease, while numerous longevity interventions result in maintenance of glucoregulatory control. In this review, we propose targeting glucose metabolism to enhance regulatory control as a means to ameliorate the aging process. We highlight that calorie restriction improves glucoregulatory control and extends both lifespan and healthspan in model organisms, but we also indicate more practical interventions (i.e., calorie restriction mimetics) are desirable for clinical application in humans. Of the calorie restriction mimetics being investigated, we focus on the type 2 diabetes drug acarbose, an $\alpha$-glucosidase inhibitor that when taken with a meal, results in reduced enzymatic degradation and absorption of glucose from complex carbohydrates. We discuss alternatives to acarbose that yield similar physiologic effects and describe dietary sources (e.g., sweet potatoes, legumes, and berries) of bioactive compounds with $\alpha$-glucosidase inhibitory activity. We indicate future research should include exploration of how non-caloric compounds like $\alpha$-glucosidase inhibitors modify macronutrient metabolism prior to disease onset, which may guide nutritional/lifestyle interventions to support health and reduce age-related disease risk.
\end{abstract}

Keywords: Glucose, aging, diabetes, disease, glucosidase inhibitor, insulin, calorie restriction

\section{Non-Standard Abbreviations:}

ACA acarbose

CR calorie restriction

CRM calorie restriction mimetic

T2D type 2 diabetes

PPG post-prandial glucose

\footnotetext{
${ }^{*}$ Corresponding author: Daniel L. Smith, Jr., PhD, Department of Nutrition Sciences, University of Alabama at Birmingham, 1720 2nd Ave S, WEBB 423, Birmingham, AL 35294, USA. Tel.: +1 205934 4086; Fax: +1 205934 7050; E-mail: dsmithjr@ uab.edu.
}

\section{Aging as a risk factor for disease}

Aging is considered the largest risk factor for a variety of chronic and metabolic diseases [1]. More than any other individual factor, advancing age increases the risk for type 2 diabetes (T2D), neurodegenerative diseases (i.e., Alzheimer's disease, Parkinson's disease), cancer, heart disease, and stroke [2-6]. Unlike many risk factors (i.e., smoking, diet, weight gain), aging, by strict definition as the act of growing old, has not historically been considered to be modifiable. Aging and risk of disease 
development are so well intertwined that skepticism surrounding the idea of longevity extension persists, as a longer lifespan is considered by some as simply a prolonged opportunity to develop additional age-related diseases [7, 8]. Despite this concern, contemporary pursuit of methods to increase lifespan and healthspan through the process of slowing the accumulation of age-related damage to cells and tissues continues [9].

Conceivably, an intervention to extend lifespan and/or healthspan would act through slowing the fundamental aging process(es) rather than preventing a single disease [10]. It is possible that interventions to slow the aging process may result in an individual experiencing an extension of healthspan without significant increases to lifespan, as it is currently unknown if maximal lifespan can be extended in humans. Therefore, an individual might experience a compressed window of morbidity by living the great majority or potentially the entirety of lifespan without developing the disorders now commonly associated with aging.

A common co-morbidity observed in aging is metabolic dysfunction [11, 12]. While metabolic (e.g., glucose and mitochondrial) dysfunction is frequently associated with aging, the causal relationship between aging and metabolic dysfunction remains to be fully understood [13, 14]. The risk relationships among age and metabolic associated diseases suggest some factors may be better primary targets for longevity interventions than others. For instance, curing cancer may not necessarily be expected to significantly affect the subsequent risk for T2D or cardiovascular disease [15]. In contrast, cardiovascular disease and T2D are more widely recognized as possible contributors to neurological disease risk and when remediated, could reduce the risk of dementia and neurodegenerative disease [16-18]. Considering the coordinate increase in risk for a number of chronic diseases with advancing age and given the unclear interrelationship between these diseases, a stronger case might be made for targeting glucoregulatory control to decrease disease risk and consequently improve longevity (Fig. 1). In fact, T2D is a significant risk factor for most other age-related diseases (e.g., cardiovascular disease, neurodegenerative disease, cancer, kidney disease) [17, 19-22]. If glycemic control were successfully maintained with advanced chronological age, this might slow the aging process, potentially delaying or preventing the development of multiple age-related diseases, allowing an individual to live healthier for longer (Fig. 1).
Exactly which cellular or molecular mechanism(s) is primarily responsible for the associations of elevated glucose with chronic disease risks is not fully understood. Proposed causative mechanisms leading to accelerated aging include direct methods such as amplified and inappropriate glycosylation events, along with the production of advanced glycation end products that damage cellular functions from DNA repair to structural integrity [23] and indirect contribution to the production of reactive oxygen species $[24,25]$. Alternatively, maintenance of glycemic control may function as a biomarker of health maintenance from the cell to the organismal level. As such, one might expect a range of interventions targeting diverse mechanisms could share this glucoregulatory phenotype, resulting from some combination of maintained integrity of the cell, organelles, hormonal signaling or other factors coordinating metabolism and ultimately aging across the organism. Thus by indirect means, changes in glucose levels could significantly impact transcriptional programs or hormonal signaling to coordinately regulate processes currently known (or unknown) to influence the aging process (e.g., mitochondrial function, autophagy) [26-30].

\section{Glucose regulation in aging}

Glucose dysregulation, measured as either hypoglycemia or hyperglycemia, can result from problems along the entire glucose uptake, production, and metabolism spectrum. Hyperglycemia is commonly associated with advancing age and can occur as a result of decreasing insulin release in response to glucose and/or increased insulin resistance by tissues $[31,32]$. T2D is diagnosed by chronically elevated blood glucose, either as a fasting blood glucose level greater than $126 \mathrm{mg} / \mathrm{dL}$ or a 2-hour post-oral glucose tolerance test blood glucose level greater than $200 \mathrm{mg} / \mathrm{dL}$, while impaired fasting glucose is the recommended diagnosis for elevated blood glucose from $110-125 \mathrm{mg} / \mathrm{dL}$ [33], both of which may be accompanied by hyperinsulinemia and/or insulin resistance.

Recent surveys of the adult population in the United States suggest that $\geq 50 \%$ of individuals over 45 years of age have T2D or prediabetes [34]. This prevalence is greater with increasing age, with $\sim 80 \%$ of older adults (age $>65$ ) showing glucose dysregulation. Thus, impaired glycemic control is approaching epidemic proportions both in the U.S. and throughout the world [35-37]. Although the source of the 

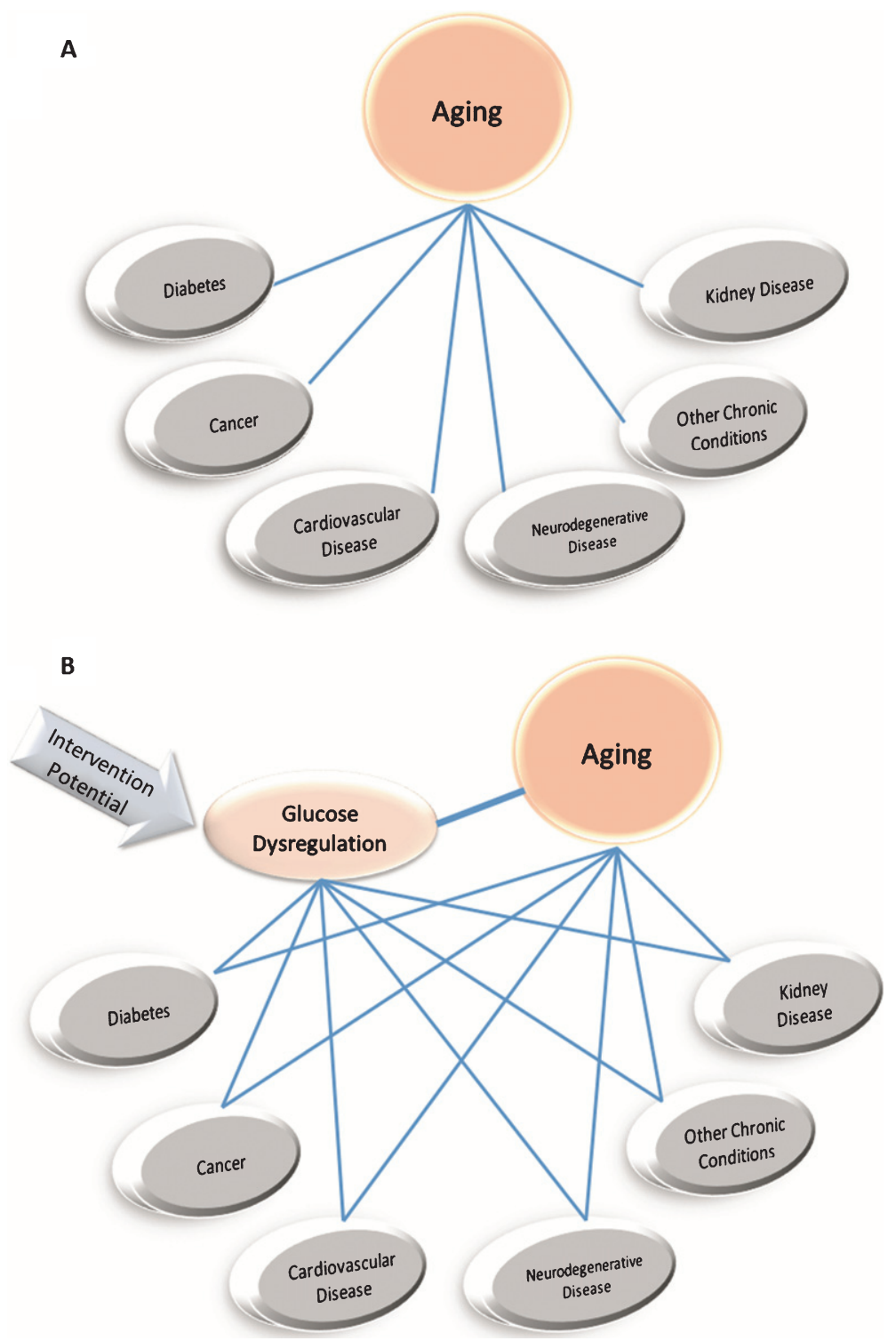

Fig. 1. Aging as a risk factor for chronic disease. A. Aging is the number one risk factor for the most prevalent metabolic and chronic diseases in developed countries. B. Glucose dysregulation, however, is also a major risk factor for many of these same "age"-related diseases, suggesting interventions that maintain or improve glucoregulatory control to prevent, delay or treat T2D (e.g., acarbose, metformin) may have manifold benefits related to other chronic diseases associated with aging.

metabolic imbalance driving glucose dysregulation may have multiple contributors, a surfeit of energy intake with increasing body weight and BMI are proposed to contribute [38]. Considering the advancing wave of senior adults in the "baby boomer" generation with their current health and fitness status, interventions targeting protection and improvements in glycemic control should hold high priority [39].

\section{Glycemic control in nutrition and genetic aging interventions}

At a metabolic level, improved glucoregulatory control is a hallmark of successful aging in multiple nutrition and genetic models across model organisms. Improved glycemic control is often present despite no obvious or significant reductions in relative 
body fatness, suggesting, independent of adiposity, glucose levels may serve as a biomarker of factors downstream or in addition to the glucose metabolism (e.g., insulin sensitivity and hormonal signaling) which may be mediating a portion of this relationship [40]. For instance, multiple preclinical, rodent models with improved longevity profiles have coincident improvements in glucose levels or insulin responsiveness, despite the nutrition or genetic interventions targeting a multiplicity of alternative pathways. Table 1 presents an overview of selected lifespan-extending interventions, summarizing the diversity of interventions with similar glucose responses. However, improved insulin sensitivity is not universally the case, as a few genetic and pharmaceutical models of increased longevity have been observed to induce insulin resistance, albeit at times still in the context of reduced circulating glucose [41-45]. These less common exceptions where longevity extension is uncoupled from improved glucose metabolism include cases where the insulin signaling pathway in the brain is disrupted resulting in increased longevity (relative to within study controls) despite mild glucose intolerance, or where downstream signaling is inhibited with normal glucose metabolism, as compared with whole body effects where insulin sensitivity is improved concomitant with increased lifespan [43, 46]. Similarly, inhibition of TOR (target of rapamycin) activity through rapamycin treatment and/or genetic means has been reported to extend lifespan in healthy, nondiabetic mice under normal laboratory conditions despite inducing some level of glucose intolerance and insulin resistance, particularly in male mice, which may be moderated (glucose intolerance) or corrected (insulin resistance) during 20 weeks of rapamycin treatment [47-50]. Additionally, intermittent rapamycin exposure may provide longevity benefits without inducing insulin resistance or glucose intolerance in mice [51]. However, other reports suggest these glucose/insulin phenotypes progress to diabetes and preempt any longevity benefit when using healthy mice under alternative housing conditions or genetic models of T2D [52-54]. Human studies of rapamycin administration following organ transplantation have also noted a predisposition to development of diabetes and poor lipemic control $[55,56]$. If the results are consistent in individuals not undergoing organ transplant, and given the hypothesis that rapamycin may be particularly detrimental to insulin regulation in conditions requiring an adaptive $\beta$-cell response [57], the metabolic dysfunction as a
Table 1

Selected lifespan extending interventions and glucose response

\begin{tabular}{|c|c|c|c|}
\hline \multirow[t]{2}{*}{ Organism } & \multicolumn{2}{|c|}{ Intervention } & \multirow[t]{2}{*}{ Glucose Level ${ }^{* *}$} \\
\hline & $\operatorname{Diet}^{\S}$ & Genetic & \\
\hline Yeast & GR & & $\boldsymbol{\nabla}[189,190]$ \\
\hline Worms & GR & & $\boldsymbol{\nabla}[191]$ \\
\hline \multirow[t]{13}{*}{ Mice/Rats } & DR & & $\boldsymbol{\nabla}[192,193]$ \\
\hline & MR & & $\boldsymbol{\nabla}[194,195]$ \\
\hline & $\mathrm{ADF}$ & & $\boldsymbol{\nabla}[196,197]$ \\
\hline & & Ames dwarf & $\boldsymbol{\nabla}[198]$ \\
\hline & & Snell dwarf & $\boldsymbol{\nabla}[199,200]$ \\
\hline & & GHR mutant & $\boldsymbol{\nabla}[201]$ \\
\hline & & FIRKO & $\boldsymbol{\nabla}[120,202]$ \\
\hline & & $\mathrm{AC} 5-\mathrm{KO}$ & $\boldsymbol{\nabla}[203-205]$ \\
\hline & & $\operatorname{Atg} 5 \mathrm{OE}$ & $\boldsymbol{\nabla}[206]$ \\
\hline & & Fgf21 OE & $\boldsymbol{\nabla}[207]$ \\
\hline & & $\alpha$ MUPA OE & $\boldsymbol{\nabla}[208]$ \\
\hline & & S6K1 KO & $\boldsymbol{\nabla}[209]$ \\
\hline & & $\mathrm{RII} \beta \mathrm{KO}$ & $\boldsymbol{\nabla}[210]$ \\
\hline
\end{tabular}

$\S_{\mathrm{GR}}=$ glucose restriction, $\mathrm{MR}=$ methionine restriction, $\mathrm{DR}=$ dietary restriction, $\mathrm{ADF}=$ alternate day fasting. ${ }^{* *}$ Represents either decreased glucose level or increased glucose tolerance/ clearance.

result of rapamycin treatment may limit its wider use. To what extent the rodent model is more permissive of glucose intolerance than the adult human and how the interplay between glucose and insulin mediates the longevity effects of these specific interventions over the full life course remains to be fully quantified and understood.

One of the most direct methods of maintaining glucose homeostasis is through diet/nutritional interventions. Paramount among these is the dietary restriction (DR) or calorie restriction (CR) paradigm. Generally speaking, CR-related increases in healthy aging and lifespan are inversely related to the amount of restriction (fewer calories = longer lifespan) and positively related to the duration of the intervention (longer duration = larger benefit) [58-60]. Within the group of homeotherms ("warm blooded" organisms), the magnitude of the benefit appears largest in smaller organisms and when started in early life [61]. While not all reports have shown longevity benefits with $\mathrm{CR}$, some even display negative health and longevity responses [62-67], the majority of publications demonstrate within-study increases in both health and longevity, albeit in laboratory strains that are most often less genetically diverse than wild populations, including humans. In most rodent CR studies, CR initiation results in temporary negative energy balance accompanied by body weight reduction (both lean and fat mass) with weight stabilization occurring within the first one to two months after 
CR initiation. This re-establishment of energy balance is maintained for the majority of the lifespan, albeit accompanied by chronic hunger, with a lower restriction limit of $\sim 60 \%$ below ad libitum ( $A L$ ) (up to $\sim 80 \%$ below AL with essential dietary component supplementation) before overt health detriment is observed in the lab [58, 61, 68, 69].

Despite these reported health benefits, life-long dietary restriction in humans remains challenging given the current state of modern society in developed countries that has shifted from a limited food supply a century ago to nutritional excess today. Additionally, it is ethically questionable whether, similar to protocols in the majority of laboratory animal models, such restriction could and/or should be enforced from a young age in humans, particularly given more recent results in non-human primate studies which provide limited support for health benefits achieved relative to a healthful diet consumed in moderation [70-72]. Therefore, the identification of interventions that promote health and longevity independent of obligatory food intake reductions has been proposed as an alternative means to "mimic" the physiologic benefits of $\mathrm{CR}$ and reap health and longevity gains - a hypothetical class of compounds termed calorie restriction mimetics (CRMs) [73-79].

Multiple compounds have been proposed as potential CRM, with many fewer demonstrating the unique capacity to increase health and lifespan significantly without inducing calorie intake reductions. Of potential CRMs targeting glucose metabolism, multiple approaches might be pursued: 1) the reduction of cellular glucose utilization with glycolytic inhibitors, 2) the reduction of circulating glucose through increased utilization or storage (e.g., insulin sensitizers) or 3) the reduction of dietary glucose access and utilization. Examples of tested glycolytic inhibitors include 2-deoxyglucose (2DG, a non-metabolizable glucose analog) and glucosamine, both of which recapitulate some of the cellular and physiologic effect of CR [80-83]. However, the ability to successfully modulate cellular glycolysis without inducing toxic side effects remains a hurdle for the non-metabolizable inhibitors like 2DG [80]. Although these compounds may have relevance to inhibiting tumor growth and specific disease states [84, 85], alternatives like glucosamine have shown promise for lifespan extension [86]. While we might suspect many compounds that modulate glucose metabolism could function as CRM (natural compounds or pharmaceuticals for T2D treatment), for the remainder of this review, we will focus largely on the third category of potential
CRMs that reduce dietary access or utilization of glucose.

\section{Targeting glucoregulatory control in aging}

The similarities between glucose dysregulation in aging and glucose dysregulation with T2D have led to the hypothesis that an effective CRM could be found by targeting glucoregulatory control [87]. If an intervention is able to improve glucose regulation to treat or prevent $\mathrm{T} 2 \mathrm{D}$, it may prevent development of glucose dysregulation commonly observed with aging (Fig. 1). The most well-known T2D drug that has been tested as a CRM is metformin [88]. Metformin is reported to act through multiple pathways; however, the best-characterized pathway is through the activation of the cellular energy regulatory sensor AMP-activated protein kinase (AMPK) [89]. AMPK has wide-reaching effects, including increasing fatty acid oxidation, autophagy and glucose uptake by skeletal muscle, as well as inhibiting gluconeogenesis in the liver [89]. As such, metformin is a first-line drug therapy in T2D hyperglycemia treatment, with over $50 \%$ of individuals receiving metformin when beginning glucose-lowering treatment [90-92]. Metformin has been shown to extend lifespan in some rodent models [88], including a possible reduction in agerelated diseases with long-term use [93]. However, the benefit of metformin has been most pronounced in disease-prone, accelerated aging or short-lived models [94]. In longer-lived, non-disease rodent strains, metformin has limited health and longevity benefits, with potential dose-dependent toxicity (similar results in Drosophila), suggesting metformin may be more effective at suppressing diseases, such as cancer, than slowing aging and extending lifespan itself [88, 95-97]. However, the extensive safety records, widespread clinical use, low cost, and presence of multiple chronic conditions with advancing age has been used to support further testing of metformin in individuals with accelerated aging or early-onset aging-related disease risk. More recent pre-clinical work has highlighted another class of diabetic control agents that work upstream of insulin (and presumably metformin-related targets) while providing health and longevity benefits in lab models - namely the $\alpha$-glucosidase inhibitor acarbose.

\section{An overview of acarbose}

Acarbose (ACA), originally BAY 5421, was isolated and identified from bacterial cultures in 1977 
by Bayer and is currently marketed in the United States for T2D under the brand name Precose [98, 99]. ACA is produced commercially from bacterial strains of Actinoplanes sp. SE50/110, though it is also produced naturally by other strains of Streptomyces and Actinoplanes bacterial species [100, 101]. ACA is a pseudo-tetrasaccharide composed of an unsaturated cyclitol unit bound to a 4,6dideoxy-D-glucopyranose, followed by a chain of three D-glucopyranose sugars connected via $\alpha-1,4$ linkages [98]. The initial two sugars form the functional inhibitory site of ACA, with the nitrogen linkage preventing hydrolysis by $\alpha-1,4$ linkagecleaving $\alpha$-glucosidases and $\alpha$-amylases. When consumed with a complex carbohydrate-containing meal, ACA acts as a competitive inhibitor to carbohydrate breakdown along the brush border of the small intestine, with a 15,000x greater affinity than sucrose for $\alpha$-glucosidase, resulting in reduced enzymatic degradation and absorption of glucose from complex carbohydrates [102]. This inhibitor effect lowers the post-prandial blood glucose elevation in a dose-dependent manner. ACA remains bound to brush-border enzymes only transiently, then is released and transits further down the gastrointestinal tract, resulting in metabolism by microbiota in the colon and cecum or elimination in the feces. No significant metabolism of ACA appears to occur when ACA is administered intravenously and $90 \%$ of ACA in the bloodstream is excreted in urine within 24 hours, with an elimination half-life of approximately 30 minutes [103].

Studies with non-diseased humans and rodents, as well as diabetic individuals, have described beneficial metabolic effects, most notably as reduced post-prandial blood glucose excursions with ACA [104, 105]. Insulin sensitivity is slightly improved with ACA, though post-prandial insulin levels do not show a consistent significant decrease [104, 106]. Glucoregulatory outcomes are sufficiently effective as to improve metabolic parameters in diabetic animal models and to decrease the number of progressions from pre-diabetes to T2D compared to a placebo in human trials [107-109]. Additionally, in a large placebo-controlled randomized clinical trial, ACA reduced risk of cardiovascular events in patients with impaired glucose tolerance, with specific decreases in risks of myocardial infarction and development of hypertension [110]. The most commonly reported side effects, as might be expected based on the mechanism of action, are flatulence, abdominal distension, and loose stools, though in rare cases ileus has been reported as well [105, 111]. Many of these side effects can be lessened through a gradual increase in ACA administration or modification of complex carbohydrate intake [112]. ACA administration typically involves a pill consumed at the start of each meal, though the most effective administration (i.e., post-prandial blood glucose mediation) occurs when powdered ACA is mixed directly into food [113].

While the molecular, inhibitory action of ACA is well-detailed, fewer studies have attempted to explore the effect ACA has on specific nutrient retention from the diet and specifically if the weight loss sometimes reported with ACA administration is the result of reduced overall energy retention from the diet. Higher levels of starches have been observed in stool of humans and animals receiving ACA compared to placebo control $[114,115]$ and one non-controlled feeding human study reported a slight, but nonsignificant, increase in total energy, nitrogen, and fat excreted [116]. Studies in our lab with mice have confirmed increased excretion of calories and carbohydrates in the feces, including glucose; however, this was balanced by increased food intake, resulting in a similar number of calories retained from the diet both with and without ACA [117]. In contrast, no alteration to caloric intake nor percentage of macronutrients utilized from the diet were observed in humans [118]. Therefore, it is unlikely that ACA acts through a simple reduction in calorie intake, availability or retention. Instead, given the important roles of insulin signaling and IGF1 in body weight homeostasis [119] and longevity [120, 121], the benefits of ACA are more likely a result of the slowed uptake of sugars from the diet, resulting in lower postprandial glucose excursions and moderated insulin responses.

\section{Acarbose and aging - current evidence}

In addition to the immediate, short-term effects on postprandial circulating glucose and insulin levels, long-term treatment with ACA produces physiologic responses that are expected with reduced calorie 'availability' [104, 105]. In rats fed a standard chow diet supplemented with ACA $(0.15 \% \mathrm{w} / \mathrm{w})$, a significant reduction in body weight gain occurred despite a significant increase in food intake compared to the controls [122]. The preponderance of reports for both mice and rats suggest that food intake is increased (or unchanged) while body weight is decreased (or unchanged) compared to controls [104, 105, 115, 
122-125]. In contrast to some other T2D medications which result in weight gain, ACA has also frequently been reported to reduce body weight in human studies [126-130]. In addition to the postprandial response with ACA, some long-term reports have shown that fasting glucose and insulin levels are reduced by ACA supplementation (although the duration of fasting and body composition should be carefully considered in these relationships). Furthermore, age-related dysregulation of glucose and insulin is partially offset by ACA supplementation $[122,131]$. This parallels nicely with the effect of CR on glucose and insulin responses in rodents and primates [132-134]. The systemic effects of ACA treatment on reduced glucose metabolism are further supported by the commonly reported reduced levels of glycated HbA1c [104, 105]. Thus, both short and long-term treatment with ACA supplementation appears to partially 'mimic' the glucose regulatory benefit observed with CR.

In 2013, a longevity study of ACA administration in healthy, non-diabetic mice was published using the F1 generation of a four-way cross of BALB/cByJ, $\mathrm{C} 57 \mathrm{BL} / 6 \mathrm{~J}, \mathrm{C} 3 \mathrm{H} / \mathrm{HeJ}$, and DBA/2J strains (UMHET3 mice) [135]. Mice in the study received $0.1 \%$ ACA in chow, beginning at four months of age. Median lifespan was significantly extended in both sexes with ACA, with a greater effect size in males (22\% increase vs. controls) than females (5\% increase), but resulting in similar median lifespans for both sexes (984 vs. 939 days, males vs. females). Additionally, both male and female mice exhibited $\sim 10 \%$ maximum lifespan increase (11\% and $9 \%$, respectively) compared to controls [135]. The differences between sexes in the early- versus late-life benefits and overall magnitude of the lifespan extension in response to ACA may have several contributing explanations. For instance, sex differences in natural longevity of UM-HET3 mice, where control females generally achieve longer median and maximum lifespans than males $[135,136]$ may obscure early- to mid-life benefits in females. Additionally, fasting insulin and IGF-1 are noted to be lower in females in this strain, along with better glucose tolerance $[48,135]$. These factors may suggest females possess improved glucose handling, and the margin for further improving glucose control compared to males is reduced. Given the relative equivalence of longevity extension with calorie restriction previously reported in both sexes of the UM-HET3 strain [137], one might speculate a sexdifferential response to specific dietary components like glucose for males and maybe protein/amino acid levels for females. Whether other longevity extending interventions that target specific pathways of nutrient signaling which show the opposite sex-preferential bias in effects (e.g., rapamycin with greater effects in females) might be pointing to such an explanation will require further study. Although a direct comparison of longevity outcomes with metformin versus acarbose has not be reported, a previous report testing $0.1 \%$ metformin treatment in one of the founding strains (C57BL/6) reported a small (5.8\%), but statistically significant benefit on mean lifespan in males; however, female mice were not included in the report [88]. Considered as a whole, even in the absence of overt disease, these data suggest targeting glucoregulatory maintenance by acarbose or other means may be a viable nutritional target for maintaining health and delaying aging.

\section{Possible alternatives to acarbose}

With the primary indication of ACA for treatment of glucose control and its mechanism of action, other treatments acting through similar glucoregulatory effects may result in beneficial outcomes as well. Three main effects of ACA include decreased post-prandial glucose (PPG) response, increased carbohydrate fermentation, and increased short-chain fatty acid (SCFA) production.

Post-prandial hyperglycemia is associated with multiple negative macro- and microvascular complications [138], thus a reduction in PPG may be expected to protect against such negative effects. ACA slows the breakdown of oligosaccharides and polysaccharides, leading to slower uptake of dietary carbohydrates and decreased PPG elevation. However, decreasing PPG can be achieved not only through a slowing of carbohydrate uptake, but also through increasing clearance or elimination rates of blood glucose. For example, sodium/glucose cotransporter 2 (SGLT2) inhibitors are able to decrease recovery of glucose from the glomerular filtrate, increasing glucose excretion [139]. They have also shown potential for improving glucose control and decreasing risk of cardiovascular disease [140, 141]. Whether an improved mechanism of glucose clearance by SGLT2 inhibition will recapitulate the health and longevity benefits observed with reduced glucose uptake remains to be demonstrated.

The main side effects of ACA (i.e., gastrointestinal discomfort, flatulence, loose stools) are due in 
part to increased microbial fermentation in the lower gut [142]. Absent ACA, most intestinal fermentation occurs as a result of dietary fiber intake, with soluble fiber generally the main source [143]. Moderate levels of dietary fiber have been proposed to be beneficial for both gut and overall organismal health [144-146], and early work by McCay et al. demonstrated extension of lifespan in rats when the diet was supplemented with 10 to $20 \%$ cellulose [146].

Resistant starches, a group of starches indigestible by human enzymes due to their structure [147], also increase fermentation in the gut when included in the diet [148]. When assessed in both pre-clinical and clinical studies, resistant starches have been associated with decreased rates of colon cancer, decreased cholesterol levels, and moderation of blood glucose levels [149-151]. Additionally, resistant starch feeding in aged mice results in improved performance on functional assessments [152] and increases in positive health-marker associated gut bacterial genera [153]. Several theories have been put forth regarding mechanisms through which resistant starches may act to improve healthspan [154] or lifespan, including more beneficial gut microbiome profiles [153, 155] and increased production of secondary metabolites such as butyrate [156-159]. To what extent resistant starches and fiber provide specific lifespan benefits similar to ACA requires further investigation.

While not directly involved with glucoregulatory control, recent studies have concluded that short chain fatty acids (SCFA) may play an important role in suppression of inflammation [160, 161]. Inflammation has been proposed as a risk factor for both aging and age-related diseases [162]; in particular, T2D displays characteristics of being both induced by and causing inflammatory states [163]. A main source of SCFA in the body derives from the byproducts of carbohydrate fermentation by gut microbiota [164]. Following production by fermentation, SCFA can be used by colonic epithelial cells as a fuel source and/or absorbed into the blood stream with subsequent tissue distribution [165]. Therefore, SCFA produced in the gut or supplemented in the diet may activate suppressors of inflammation, leading to decreased chronic inflammation and delayed development of age-related diseases. The availability of carbohydrates for fermentation in the colon may support shifts in gut microbial communities and facilitate SCFA production. ACA treatment in rats leads to increased levels of SCFA in the colon [115], and shifts in microbial communities with increased Bifidobacteria have been documented in T2D patients receiving ACA supplement to anti-diabetic medications [166], as well as both increased Lactobacilli and Bifidobacteria in hyperlipidemic patients with ACA [167]. Additional human studies of ACA supplementation have also demonstrated increased colonic butyrate production, likely from the observed concurrent increases in starch-fermenting bacteria as a percentage of total fecal anaerobes [114]. The degree to which ACA alone (as a compound produced by bacteria) or SCFA production drives changes in the gut microbial community remains to be determined. However, reduced inflammatory cytokines (i.e., LPS) have been noted in T2D patients given ACA supplement to prescribed anti-diabetic medications [166]. It is becoming increasingly clear that our understanding of interactions and dependence of glucose-lowering drugs on the gut and resident microbiota with health outcomes is still far from complete. For instance, the longevity benefit of metformin in the C. elegans model depends on alterations in bacterial metabolism ultimately affecting the host lifespan [168]. Furthermore, the glucose-lowering mechanism of metformin appears to be significantly influenced by the lower gut and bacterial populations associated with SCFA production [169, 170]. Future studies using gnotobiotic or germ-free rodent models may be able to further clarify the contribution of microbial fermentation byproducts in the health and longevity benefits of ACA and alternative interventions.

\section{Naturally-occurring acarbose mimetics}

While ACA is bacterially derived and purified, other compounds with similar $\alpha$-glucosidase or $\alpha$ amylase inhibitory activity are found in multiple naturally-occurring dietary sources. In particular, a variety of leguminous plants contain inhibitory activity against both $\alpha$-glucosidases and $\alpha$-amylases [171]. Animal studies have confirmed the ability of many of these naturally occurring $\alpha$-glucosidase or $\alpha$-amylase inhibitors to reduce blood glucose levels and improve overall health status [172-175]. In fact, based on in vitro and ex vivo testing, plant-derived $\alpha$ glucosidase or $\alpha$-amylase inhibitors from seeds, bark, leaves, and fruits of many plant varieties often have equivalent or greater inhibitory activity than ACA and related pharmaceutical compounds [176-178]. Cinnamon in particular has gained recent attention as an effective $\alpha$-glucosidase and $\alpha$-amylase inhibitor significantly reducing PPG in response to maltose and 
sucrose-load in diabetic rats $[179,180]$, with clinical data showing similar possibilities [181].

Considering the number of $\alpha$-glucosidase and $\alpha$ amylase inhibitors identified from such a diverse selection of plants, it is likely additional compounds with similar inhibitory properties may be present, but currently unidentified, in many commonly eaten foods. Eating a diet rich in foods containing botanicals with sufficient concentrations/activity of these phytochemicals may conceivably provide $\alpha$ glucosidase and $\alpha$-amylase inhibitor outcomes equal to or greater than those achieved through pharmaceutical interventions as monotherapies (e.g., ACA at specific dosages). Anecdotal evidence potentially supports this notion. For instance, Okinawan cohorts recognized for exceptional health and longevity previously consumed high levels of sweet potatoes in their diet relative to the general population in Japan and other contemporary cohort countries, estimated to previously constitute $\sim 69 \%$ of total daily dietary calories [182, 183]. Sweet potatoes (Ipomoea batatas) are rich in fiber, with higher vitamin and mineral concentrations than many other natural starches such as rice or refined carbohydrates [184]. Additionally, sweet potatoes come in a variety of colors with diverse phytochemicals (e.g., anthocyanins and polyphenols), which have multiple proposed biochemical and health benefits, with particularly remarkable $\alpha$-glucosidase and $\alpha$-amylase inhibitory activity [185-187]. Similarly, curcumin-rich foods, best known for antioxidant properties, were also a staple for the Okinawan cohorts [183], and also contain $\alpha$-glucosidase inhibitory properties [188]. Moving beyond the simple calorie, macronutrient, and micronutrient composition of a given food to a deeper understanding of the biologically active and non-caloric compounds present in foods, as well as how those modify nutrient access and utilization, would build on longstanding knowledge and tradition of healthy dietary components.

\section{Conclusions}

ACA has proven to be an effective means for reducing PPG and improving glucose regulation in individuals with T2D. Additionally, animal work has demonstrated a role for ACA in extending both healthspan and lifespan of non-diabetic models. These positive outcomes with ACA may result from a combination of several biological mechanisms; however, multiple health and longevity extending interventions (nutrition and genetic) support the idea that the benefits of ACA reflect improved glucose regulation. ACA trials in non-diabetic human populations could be further explored, given the potential for beneficial health and aging outcomes, the limited side effects, extensive clinical history of use for T2D, and minimal costs. Such trials may be especially relevant to address the prediabetic state of metabolic syndrome in middle age or older populations. Additionally, as multiple compounds in plants and foods exhibit similar inhibitory properties, increased research into these naturally occurring compounds seems warranted. A greater understanding of how non-caloric compounds like $\alpha$-glucosidase or $\alpha$-amylase inhibitors modify macronutrient metabolism holds promise for nutritional/lifestyle interventions as a form of preventative medicine to support health and reduce age-related disease risk.

\section{Acknowledgments}

The compilation of this publication was supported by the National Institute on Aging of the National Institutes of Health under award number R01AG043972, the Ellison Medical Foundation New Scholar in Aging award, and the University of Alabama at Birmingham Nathan Shock Center of Excellence in the Biology of Aging (P30AG050886). Preparation of this manuscript was supported in part by NIH training grant T32DK062710 UAB Obesity Post-Doctoral Training Program to VKG. The views and opinions expressed herein are those of the authors and do not necessarily reflect the official policy or position of any funding source or agency with which the authors are affiliated. RAB is a current employee of USANA Health Sciences, Inc., Salt Lake City, Utah. DLS and VKG report no conflicts of interest.

\section{References}

[1] Harman D. The aging process: Major risk factor for disease and death. Proc Natl Acad Sci. 1991;88(12):5360-3.

[2] Kannel WB, McGee DL. Diabetes and cardiovascular risk factors: The Framingham study. Circulation. 1979;59(1): $8-13$.

[3] Lindsay J, Laurin D, Verreault R, Hébert R, Helliwell B, Hill GB, McDowell I. Risk factors for Alzheimer's disease: A prospective analysis from the Canadian Study of Health and Aging. Am J Epidemiol. 2002;156(5): 445-53. 
[4] Doll R. The age distribution of cancer: Implications for models of carcinogenesis. J R Stat Soc Ser A. 1971; 134(2):133.

[5] Wilson PWF, D'Agostino RB, Levy D, Belanger A, Silbershatz H, Kannel WB. Prediction of coronary heart disease using risk factor categories. Circulation. 1998;97(18):183747.

[6] Wolf PA, Abbott RD, Kannel WB. Atrial fibrillation as an independent risk factor for stroke: The Framingham Study. Stroke. 1991;22(8):983-8.

[7] Olshansky S, Carnes B, Cassel C. In search of Methuselah: Estimating the upper limits to human longevity. Science. 1990;250(4981):634-40.

[8] Vijg J, Campisi J. Puzzles, promises and a cure for ageing. Nature. 2008;454(7208):1065-71.

[9] Olshansky SJ, Hayflick L, Carnes BA. Position statement on human aging. Journals Gerontol Ser A Biol Sci Med Sci. 2002;57(8):B292-7.

[10] Niccoli T, Partridge L. Ageing as a risk factor for disease. Curr Biol. 2012;22(17):R741-52.

[11] Orozco-Solis R, Sassone-Corsi P. Circadian clock: Linking epigenetics to aging. Curr Opin Genet Dev. 2014;26:66-72.

[12] Biolo G, Cederholm T, Muscaritoli M. Muscle contractile and metabolic dysfunction is a common feature of sarcopenia of aging and chronic diseases: From sarcopenic obesity to cachexia. Clin Nutr. 2014;33(5):737-48.

[13] Barzilai N, Huffman DM, Muzumdar RH, Bartke A. The critical role of metabolic pathways in aging. Diabetes. 2012;61(6):1315-22.

[14] DiStefano PS, Curtis R, Geddes BJ. Insulin resistance, glycemic control and adiposity: Key determinants of healthy lifespan. Curr Alzheimer Res. 2007;4(2):153-7.

[15] Liu L, Wylie RC, Andrews LG, Tollefsbol TO. Aging, cancer and nutrition: The DNA methylation connection. Mech Ageing Dev. 2003;124(10-12):989-98.

[16] Qiu C, Fratiglioni L. A major role for cardiovascular burden in age-related cognitive decline. Nat Rev Cardiol. 2015;12(5):267-77.

[17] Chatterjee S, Peters SAE, Woodward M, Arango SM, Batty GD, Beckett N, Beiser A, Borenstein AR, Crane PK, Haan M, Hassing LB, Hayden KM, Kiyohara Y, Larson EB, Li C-Y, Ninomiya T, Ohara T, Peters R, Russ TC, Seshadri S, Strand BH, Walker R, Xu W, Huxley RR. Type 2 diabetes as a risk factor for dementia in women compared with men: $\mathrm{A}$ pooled analysis of 2.3 million people comprising more than 100,000 cases of dementia. Diabetes Care. 2015;dc151588.

[18] Nelson L, Tabet N. Slowing the progression of Alzheimer's disease; what works? Ageing Res Rev. 2015;23(Pt B):193209.

[19] Ma RC. Genetics of cardiovascular and renal complications in diabetes. J Diabetes Investig. 2016;7(2):139-54.

[20] The Emerging Risk Factors Collaboration. Diabetes mellitus, fasting blood glucose concentration, and risk of vascular disease: A collaborative meta-analysis of 102 prospective studies. Lancet. 2010;375(9733):2215-22.

[21] Bourne RRA, Stevens GA, White RA, Smith JL, Flaxman SR, Price H, Jonas JB, Keeffe J, Leasher J, Naidoo K, Pesudovs K, Resnikoff S, Taylor HR. Causes of vision loss worldwide, 1990-2010: A systematic analysis. Lancet Glob Heal. 2013;1(6):e339-49.

[22] Tesfaye S, Stevens LK, Stephenson JM, Fuller JH, Plater M, Ionescu-Tirgoviste C, Nuber A, Pozza G, Ward JD.
Prevalence of diabetic peripheral neuropathy and its relation to glycaemic control and potential risk factors: The EURODIAB IDDM Complications Study. Diabetologia. 1996;39(11):1377-84.

[23] Banerjee PS, Lagerlöf O, Hart GW. Roles of O-GlcNAc in chronic diseases of aging. Mol Aspects Med. 2016;

[24] Stadtman ER, Berlett BS. Reactive oxygen-mediated protein oxidation in aging and disease. Drug Metab Rev. 1998;30(2):225-43.

[25] Ramasamy R, Vannucci SJ, Yan SS Du, Herold K, Yan SF, Schmidt AM. Advanced glycation end products and RAGE: A common thread in aging, diabetes, neurodegeneration, and inflammation. Glycobiology. 2005;15(7):16R-28.

[26] Moruno F, Pérez-Jiménez E, Knecht E. Regulation of autophagy by glucose in mammalian cells. Cells. 2012;1(3).

[27] Montgomery MK, Turner N. Mitochondrial dysfunction and insulin resistance: An update. Endocr Connect. 2015; 4(1):R1-15.

[28] Dassanayaka S, Readnower RD, Salabei JK, Long BW, Aird AL, Zheng Y-T, Muthusamy S, Facundo HT, Hill BG, Jones SP. High glucose induces mitochondrial dysfunction independently of protein O-GlcNAcylation. Biochem J. 2015;467(1):115-26.

[29] Bratic A, Larsson N-G. The role of mitochondria in aging. J Clin Invest. The American Society for Clinical Investigation. 123(3):951-7.

[30] Riera CE, Dillin A. Tipping the metabolic scales towards increased longevity in mammals. Nat Cell Biol. 2015;17(3):196-203.

[31] Leiter LA, Ceriello A, Davidson JA, Hanefeld M, Monnier L, Owens DR, Tajima N, Tuomilehto J. Postprandial glucose regulation: New data and new implications. Clin Ther. 2005;27:S42-56.

[32] Reaven GM. Role of insulin resistance in human disease. Diabetes. 1988;37(12):1595-607.

[33] World Health Organization, International Diabetes Federation. Definition and diagnosis of diabetes mellitus and intermediate hyperglycaemia: Report of a WHO/IDF consultation. Geneva: World Health Organization; 2006.

[34] Menke A, Casagrande S, Geiss L, Cowie CC. Prevalence of and trends in diabetes among adults in the United States, 1988-2012. JAMA. 2015;314(10): 1021.

[35] Chen X, Yang W. Epidemic trend of diabetes in China: For the Xiaoren Pan distinguished research Award in AASD. J Diabetes Investig. 2014;5(5):478-81.

[36] Sherif S, Sumpio BE. Economic development and diabetes prevalence in MENA countries: Egypt and Saudi Arabia comparison. World J Diabetes. 2015;6(2):304-11.

[37] Weber MB, Oza-Frank R, Staimez LR, Ali MK, Narayan KM. Type 2 diabetes in Asians: Prevalence, risk factors, and effectiveness of behavioral intervention at individual and population levels. Annu Rev Nutr. 2012;32:417-39.

[38] Mokdad AH, Bowman BA, Ford ES, Vinicor F, Marks JS, Koplan JP. The continuing epidemics of obesity and diabetes in the United States. JAMA. 2001;286(10):1195.

[39] King DE, Matheson E, Chirina S, Shankar A, BromanFulks J. The status of baby boomers' health in the united states. JAMA Intern Med. 2013;173(5):385-6.

[40] DiPietro L, Seeman TE, Stachenfeld NS, Katz LD, Nadel ER. Moderate-intensity aerobic training improves glucose tolerance in aging independent of abdominal adiposity. J Am Geriatr Soc. 1998;46(7):875-9. 
[41] Selman C, Lingard S, Choudhury AI, Batterham RL, Claret M, Clements M, Ramadani F, Okkenhaug K, Schuster E, Blanc E, Piper MD, Al-Qassab H, Speakman JR, Carmignac D, Robinson ICA, Thornton JM, Gems D, Partridge L, Withers DJ. Evidence for lifespan extension and delayed age-related biomarkers in insulin receptor substrate 1 null mice. FASEB J. 2007;22(3):807-18.

[42] Kappeler L, De Magalhaes Filho C, Dupont J, Leneuve P, Cervera P, Périn L, Loudes C, Blaise A, Klein R, Epelbaum J, Le Bouc Y, Holzenberger M. Brain IGF-1 receptors control mammalian growth and lifespan through a neuroendocrine mechanism. PLoS Biol. 2008;6(10):e254.

[43] Taguchi A, Wartschow LM, White MF. Brain IRS2 signaling coordinates life span and nutrient homeostasis. Science. 2007;317(5836):369-72.

[44] Kurosu H. Suppression of aging in mice by the hormone klotho. Science. 2005;309(5742):1829-33.

[45] Houde VP, Brule S, Festuccia WT, Blanchard PG, Bellmann K, Deshaies Y, Marette A. Chronic rapamycin treatment causes glucose intolerance and hyperlipidemia by upregulating hepatic gluconeogenesis and impairing lipid deposition in adipose tissue. Diabetes. 2010;59(6): 1338-48.

[46] Nojima A, Yamashita M, Yoshida Y, Shimizu I, Ichimiya H, Kamimura N, Kobayashi Y, Ohta S, Lansdorp P, et al. Haploinsufficiency of akt1 prolongs the lifespan of mice. Sadoshima J, editor. PLoS One. Public Library of Science. 2013;8(7):e69178.

[47] Fang Y, Westbrook R, Hill C, Boparai RK, Arum O, Spong A, Wang F, Javors MA, Chen J, Sun LY, Bartke A. Duration of rapamycin treatment has differential effects on metabolism in mice. Cell Metab. 2013;17(3):456-62.

[48] Miller RA, Harrison DE, Astle CM, Fernandez E, Flurkey K, Han M, Javors MA, Li X, Nadon NL, Nelson JF, Pletcher S, Salmon AB, Sharp ZD, Van Roekel S, Winkleman L, Strong R. Rapamycin-mediated lifespan increase in mice is dose and sex dependent and metabolically distinct from dietary restriction. Aging Cell. 2014;13(3):468-77.

[49] Lamming DW, Ye L, Katajisto P, Goncalves MD, Saitoh M, Stevens DM, Davis JG, Salmon AB, Sancak Y, et al. Rapamycin-induced insulin resistance is mediated by mTORC2 loss and uncoupled from longevity. Science. 2012;335(6076):1638-43.

[50] Wu JJ, Liu J, Chen EB, Wang JJ, Cao L, Narayan N, Fergusson MM, Rovira II, Allen M, Springer DA, Lago CU, Zhang S, DuBois W, Ward T, deCabo R, Gavrilova O, Mock B, Finkel T. Increased Mammalian Lifespan and a Segmental and Tissue-Specific Slowing of Aging after Genetic Reduction of mTOR Expression. Vol. 4, Cell Reports. 2013.

[51] Arriola Apelo SI, Pumper CP, Baar EL, Cummings NE, Lamming DW. Intermittent administration of rapamycin extends the life span of female C57BL/6J mice. Journals Gerontol Ser A Biol Sci Med Sci. 2016.

[52] Sataranatarajan K, Ikeno Y, Bokov A, Feliers D, Yalamanchili H, Lee HJ, Mariappan MM, Tabatabai-Mir H, Diaz V, Prasad S, Javors MA, Ghosh Choudhury G, Hubbard GB, Barnes JL, Richardson A, Kasinath BS. Rapamycin increases mortality in $\mathrm{db} / \mathrm{db}$ mice, a mouse model of type 2 diabetes. Journals Gerontol Ser A Biol Sci Med Sci. 2016;71(7):850-7.

[53] Schindler CE, Partap U, Patchen BK, Swoap SJ. Chronic rapamycin treatment causes diabetes in male mice. Am J
Physiol - Regul Integr Comp Physiol. 2014;307(4):R43443.

[54] Gibbs VK, Smith DL. Nutrition and Energetics in Rodent Longevity Research. Exp Gerontol. 2016. [http://dx.doi.org/10.1016/j.exger.2016.04.004

[55] Gyurus E, Kaposztas Z, Kahan BD. Sirolimus therapy predisposes to new-onset diabetes mellitus after renal transplantation: A long-term analysis of various treatment regimens. Transplant Proc. 2011;43(5):1583-92.

[56] Claes K, Meier-Kriesche H-U, Schold JD, Vanrenterghem Y, Halloran PF, Ekberg H. Effect of different immunosuppressive regimens on the evolution of distinct metabolic parameters: Evidence from the Symphony study. Nephrol Dial Transplant. 2012;27(2):850-7.

[57] Vodenik B, Rovira J, Campistol JM. Mammalian target of rapamycin and diabetes: What does the current evidence tell us? Transplant Proc. 2009;41(6):S31-8.

[58] Weindruch R, Walford RL. Retardation of aging and disease by dietary restriction. CC Thomas; 1988.

[59] Weindruch R. The retardation of aging by caloric restriction: Studies in rodents and primates. Toxicol Pathol. 1996;24(6):742-5.

[60] Merry B. Molecular mechanisms linking calorie restriction and longevity. Int J Biochem Cell Biol. 2002;34(11):134054.

[61] Speakman JR, Hambly C. Starving for life: What animal studies can and cannot tell us about the use of caloric restriction to prolong human lifespan. J Nutr. 2007;137(4) :1078-86.

[62] Forster MJ. Genotype and age influence the effect of caloric intake on mortality in mice. FASEB J. 2003;17(6):690-2.

[63] Harper JM, Leathers CW, Austad SN. Does caloric restriction extend life in wild mice? Aging Cell. 2006;5(6):441-9.

[64] Liao CY, Rikke BA, Johnson TE, Diaz V, Nelson JF. Genetic variation in the murine lifespan response to dietary restriction: From life extension to life shortening. Aging Cell. 2010;9(1):92-5.

[65] Lipman RD, Smith DE, Bronson RT, Blumberg J. Is late-life caloric restriction beneficial? Aging. 1995;7(2):136-9.

[66] Lipman RD, Smith DE, Blumberg JB, Bronson RT. Effects of caloric restriction or augmentation in adult rats: Longevity and lesion biomarkers of aging. Aging Clin Exp Res. 1998;10(6):463-70.

[67] Lipman RD, Dallal GE, Bronson RT. Effects of genotype and diet on age-related lesions in ad libitum fed and calorierestricted F344, BN, and BNF3F1 rats. Journals Gerontol Ser A Biol Sci Med Sci. 1999;54(11):B478-91.

[68] Weindruch R, Sohal RS. Seminars in medicine of the Beth Israel Deaconess Medical Center. Caloric intake and aging. N Engl J Med. 1997;337(14):986-94.

[69] Hambly C, Mercer JG, Speakman JR. Hunger does not diminish over time in mice under protracted caloric restriction. Rejuvenation Res. 2007;10(4):533-42.

[70] Colman RJ, Anderson RM, Johnson SC, Kastman EK, Kosmatka KJ, Beasley TM, Allison DB, Cruzen C, Simmons HA, Kemnitz JW, Weindruch R. Caloric restriction delays disease onset and mortality in rhesus monkeys. Science. 2009;325(5937):201-4.

[71] Mattison JA, Roth GS, Beasley TM, Tilmont EM, Handy AM, Herbert RL, Longo DL, Allison DB, Young JE, Bryant M, Barnard D, Ward WF, Qi W, Ingram DK, de Cabo R. Impact of caloric restriction on health and survival in rhe- 
sus monkeys from the NIA study. Nature. 2012;489(7415): 318-21.

[72] Colman RJ, Beasley TM, Kemnitz JW, Johnson SC, Weindruch R, Anderson RM. Caloric restriction reduces age-related and all-cause mortality in rhesus monkeys. Nat Commun. 2014;5:3557.

[73] Dhahbi JM, Mote PL, Fahy GM, Spindler SR. Identification of potential caloric restriction mimetics by microarray profiling. Physiol Genomics. 2005;23(3):343-50.

[74] Ingram DK, Anson RM, de Cabo R, Mamczarz J, Zhu M, Mattison J, Lane MA, Roth GS. Development of calorie restriction mimetics as a prolongevity strategy. Ann N Y Acad Sci. 2004;1019:412-23.

[75] Ingram DK, Zhu M, Mamczarz J, Zou S, Lane MA, Roth GS, DeCabo R. Calorie restriction mimetics: An emerging research field. Aging Cell. 2006;5(2):97-108.

[76] Lane MA, Mattison J, Ingram DK, Roth GS. Caloric restriction and aging in primates: Relevance to humans and possible CR mimetics. Microsc Res Tech. 2002;59(4): 335-8.

[77] Lane MA, de Cabo R, Mattison J, Anson R., Roth GS, Ingram DK. The Roy Walford legacy: Diet restriction from molecules to mice to monkeys to man and onto mimetics. Exp Gerontol. 2004;39(6):897-902.

[78] Lane MA, Roth GS, Ingram DK. Caloric restriction mimetics: A novel approach for biogerontology. Methods Mol Biol. 2007;371:143-9.

[79] Roth GS, Lane MA, Ingram DK. Caloric restriction mimetics: The next phase. Ann N Y Acad Sci. 2005;1057: 365-71.

[80] Minor RK, Smith DL Jr, Sossong AM, Kaushik S, Poosala S, Spangler EL, Roth GS, Lane M, Allison DB, de Cabo R, Ingram DK, Mattison JA. Chronic ingestion of 2-deoxy-d-glucose induces cardiac vacuolization and increases mortality in rats. Toxicol Appl Pharmacol. 2010;243(3):332-9.

[81] Ingram DK, Roth GS. Glycolytic inhibition as a strategy for developing calorie restriction mimetics. Exp Gerontol. 2011;46(2-3):148-54.

[82] Roth GS, Ingram DK, Lane MA. Caloric restriction in primates and relevance to humans. Ann N Y Acad Sci. Wiley Online Library. 2001;928(1):305-15.

[83] Lane MA, Ingram DK, Roth GS. 2-Deoxy-D-glucose feeding in rats mimics physiologic effects of calorie restriction. J Anti Aging Med. 1998;1(4):327-37.

[84] Gridley DS, Nutter RL, Kettering JD, Mantik DW, Slater JM. Mouse neoplasia and immunity: Effects of radiation, hyperthermia, 2-deoxy-D-glucose, and corynebacterium parvum. Oncology. 1985;42(6):391-8.

[85] Zhu Z, Jiang W, McGinley JN, Thompson HJ. 2Deoxyglucose as an energy restriction mimetic agent: Effects on mammary carcinogenesis and on mammary tumor cell growth in vitro. Cancer Res. 2005;65(15):702330.

[86] Weimer S, Priebs J, Kuhlow D, Groth M, Priebe S, Mansfeld J, Merry TL, Dubuis S, Laube B, Pfeiffer AF, Schulz TJ, Guthke R, Platzer M, Zamboni N, Zarse K, Ristow M. D-Glucosamine supplementation extends life span of nematodes and of ageing mice. Nat Commun. 2014;5:3563.

[87] Dirks AJ, Leeuwenburgh C. Caloric restriction in humans: Potential pitfalls and health concerns. Mech Ageing Dev. 2006;127(1):1-7.
[88] Martin-Montalvo A, Mercken EM, Mitchell SJ, Palacios HH, Mote PL, Scheibye-Knudsen M, Gomes AP, Ward TM, Minor RK, Blouin M-J, Schwab M, Pollak M, Zhang Y, Yu Y, Becker KG, Bohr VA, Ingram DK, Sinclair DA, Wolf NS, Spindler SR, Bernier M, de Cabo R. Metformin improves healthspan and lifespan in mice. Nat Commun. 2013;4:2192.

[89] Zhou G, Myers R, Li Y, Chen Y, Shen X, Fenyk-Melody J, Wu M, Ventre J, Doebber T, Fujii N, Musi N, Hirshman MF, Goodyear LJ, Moller DE. Role of AMP-activated protein kinase in mechanism of metformin action. J Clin Invest. 2001;108(8):1167-74.

[90] Bennett WL, Maruthur NM, Singh S, Segal JB, Wilson LM, Chatterjee R, Marinopoulos SS, Puhan MA, Ranasinghe P, Block L, Nicholson WK, Hutfless S, Bass EB, Bolen S. Comparative effectiveness and safety of medications for type 2 diabetes: An update including new drugs and 2-drug combinations. Ann Intern Med. 2011;154(9):602-13.

[91] Standl E, Schnell O. Insulin as a first-line therapy in type 2 diabetes: Should the use of sulfonylureas be halted? Diabetes Care. 2008;31(Supplement 2):S136-9.

[92] Berkowitz SA, Krumme AA, Avorn J, Brennan T, Matlin OS, Spettell CM, Pezalla EJ, Brill G, Shrank WH, Choudhry NK. Initial choice of oral glucose-lowering medication for diabetes mellitus. JAMA Intern Med. 2014; 174(12): 1955 .

[93] Ingram DK, Roth GS. Calorie restriction mimetics: Can you have your cake and eat it, too? Ageing Res Rev. 2015;20: 46-62.

[94] Anisimov VN. Metformin: Do we finally have an anti-aging drug? Cell Cycle. 2013;12(22):3483-9.

[95] Smith DL, Elam CF, Mattison JA, Lane MA, Roth GS, Ingram DK, Allison DB. Metformin supplementation and life span in fischer-344 rats. Journals Gerontol Ser A Biol Sci Med Sci. 2010;65A(5):468-74.

[96] Slack C, Foley A, Partridge L. Activation of AMPK by the putative dietary restriction mimetic metformin is insufficient to extend lifespan in drosophila. Roman G, editor. PLoS One. 2012;7(10):e47699.

[97] Strong R, Miller RA, Antebi A, Astle CM, Bogue M, Denzel MS, Fernandez E, Flurkey K, Hamilton KL, Lamming DW, Javors MA, de Magalhães JP, Martinez PA, McCord JM, Miller BF, Müller M, Nelson JF, Ndukum J, Rainger GE, Richardson A, Sabatini DM, Salmon AB, Simpkins JW, Steegenga WT, Nadon NL, Harrison DE. Longer lifespan in male mice treated with a weakly estrogenic agonist, an antioxidant, an $\alpha$-glucosidase inhibitor or a Nrf2-inducer. Aging Cell. 2016. doi:10.1111/acel.12496

[98] Schmidt DD, Frommer W, Junge B, Mueller L, Wingender W, Truscheit E. a-Glucosidase inhibitors: new complex oligosaccharides of microbial origin. Naturwissenschaften. 1977;64:535-7.

[99] Puls W, Keup U, Krause HP, Thomas G, Hoffmeister F. Glucosidase inhibition. Naturwissenschaften. 1977;64(10):536-7.

[100] Rockser Y, Wehmeier UF. The gac-gene cluster for the production of acarbose from Streptomyces glaucescens GLA.O-Identification, isolation and characterization. J Biotechnol. 2009;140(1-2):114-23.

[101] Wehmeier UF, Piepersberg W. Biotechnology and molecular biology of the alpha-glucosidase inhibitor acarbose. Appl Microbiol Biotechnol. 2004;63(6):613-25. 
[102] Caspary WF, Graf S. Inhibition of human intestinal $\alpha$ glucosidehydrolases by a new complex oligosaccharide. Res Exp Med. 1979;175(1):1-6.

[103] Salvatore T, Giugliano D. Pharmacokinetic-Pharmacodynamic Relationships of Acarbose. Clin Pharmacokinet. 1996;30(2):94-106.

[104] Balfour JA, McTavish D. Acarbose: An update of its pharmacology and therapeutic use in diabetes mellitus. Drugs. 1993;46(6):1025-54.

[105] Clissold SP, Acarbose EC. A preliminary review of its pharmacodynamic and pharmacokinetic properties, and therapeutic potential. Drugs. 1988;35(3):214-43.

[106] Martin AE, Montgomery PA. Acarbose: An alphaglucosidase inhibitor. Am J Heal Pharm. 1996;53(19): 2277-90.

[107] Chiasson J-L, Josse RG, Gomis R, Hanefeld M, Karasik A, Laakso M. Acarbose for prevention of type 2 diabetes mellitus: The STOP-NIDDM randomised trial. Lancet. 2002;359(9323):2072-7.

[108] Azuma K, Toyofuku Y, Iesaki T, Otsuka A, Tanaka A, Mita T, Hirose T, Tanaka Y, Daida H, Kawamori R, Watada H. Acarbose, an $\alpha$-glucosidase inhibitor, improves endothelial dysfunction in Goto-Kakizaki rats exhibiting repetitive blood glucose fluctuation. Biochem Biophys Res Commun. 2006;345(2):688-93.

[109] Katovich MJ, Meldrum MJ, Vasselli JR. Beneficial effects of dietary acarbose in the streptozotocin-induced diabetic rat. Metabolism. 1991;40(12):1275-82.

[110] Chiasson J-L, Josse RG, Gomis R, Hanefeld M, Karasik A, Laakso M, for The STOP-NIDDM Trial Research Group. Acarbose treatment and the risk of cardiovascular disease and hypertension in patients with impaired glucose tolerance. JAMA. 2003;290(4):486.

[111] Nishii Y, Aizawa T, Hashizume K. Ileus: A rare side effect of acarbose. Diabetes Care. 1996;19(9):1033.

[112] McCarty MF, DiNicolantonio JJ. Acarbose, lente carbohydrate, and prebiotics promote metabolic health and longevity by stimulating intestinal production of GLP-1. Open Hear. 2015;2(1):e00205.

[113] O'Dea K, Turton J. Optimum effectiveness of intestinal aglucosidase inhibitors: Importance of uniform distribution through a meal. Am J Clin Nutr. 1985;41(3):511-6.

[114] Weaver GA, Tangel CT, Krause JA, Parfitt MM, Jenkins PL, Rader JM, Lewis BA, Miller TL, Wolin MJ. Acarbose enhances human colonic butyrate production. J Nutr. 1997;127(5):717-23.

[115] Dehghan-Kooshkghazi M, Mathers JC. Starch digestion, large-bowel fermentation and intestinal mucosal cell proliferation in rats treated with the $\alpha$-glucosidase inhibitor acarbose. Br J Nutr. 2004;91(03):357.

[116] Holt PR, Atillasoy E, Lindenbaum J, Ho SB, Lupton JR, McMahon D, Moss SF. Effects of acarbose on fecal nutrients, colonic $\mathrm{pH}$, and short-chain fatty acids and rectal proliferative indices. Metabolism. 1996;45(9): 1179-87.

[117] Brewer RA. The alpha-glucosidase inhibitor acarbose as a calorie restriction mimetic to modify metabolic outcomes in mice. University of Alabama at Birmingham;Ph.D. Dissertation, 2015.

[118] Ahr H, Bomhard E, Schmidt U, Schluter G. Acarbose and acetaminophen: A dangerous combination? Hepatology. 1999;30(1):341-2.
[119] Brüning JC, Gautam D, Burks DJ, Gillette J, Schubert M, Orban PC, Klein R, Krone W, Müller-Wieland D, Kahn CR. Role of brain insulin receptor in control of body weight and reproduction. Science. 2000;289(5487):2122-5.

[120] Bluher M. Extended longevity in mice lacking the insulin receptor in adipose tissue. Science. 2003;299(5606):572-4.

[121] Holzenberger M, Dupont J, Ducos B, Leneuve P, Geloen A, Even PC, Cervera P, Le Bouc Y. IGF-1 receptor regulates lifespan and resistance to oxidative stress in mice. Nature. 2003;421(6919):182-7.

[122] Yamamoto M, Otsuki M. Effect of inhibition of $\alpha$ glucosidase on age-related glucose intolerance and pancreatic atrophy in rats. Metab - Clin Exp. Elsevier. 2006;55(4): 533-40.

[123] Paiva L, Binsack R, Machado UF. Chronic acarbosefeeding increases GLUT1 protein without changing intestinal glucose absorption function. Eur J Pharmacol. 2002; 434(3):197-204.

[124] Lee SM, Bustamante SA, Koldovský O. The effect of alphaglucosidase inhibition on intestinal disaccharidase activity in normal and diabetic mice. Metabolism. 1983;32(8): 793-9.

[125] Vedula U, Schnitzer-Polokoff R, Tulp OL. The effect of acarbose on the food intake, weight gain, and adiposity of LA/N-cp rats. Comp Biochem Physiol Part A Physiol. 1991;100(2):477-82.

[126] Willms B, Ruge D. Comparison of acarbose and metformin in patients with Type 2 diabetes mellitus insufficiently controlled with diet and sulphonylureas: A randomized, placebo-controlled study. Diabet Med. 1999;16(9):755-61.

[127] Li Y, Tong Y, Zhang Y, Huang L, Wu T, Tong N. Acarbose monotherapy and weight loss in Eastern and Western populations with hyperglycaemia: An ethnicity-specific meta-analysis. Int J Clin Pract. 2014;68(11):1318-32.

[128] Sun W, Zeng C, Liao L, Chen J, Wang Y. Comparison of acarbose and metformin therapy in newly diagnosed type 2 diabetic patients with overweight and/or obese. Curr Med Res Opin. 2016;1-34.

[129] Pan C, Yang W, Barona JP, Wang Y, Niggli M, Mohideen P, Wang Y, Foley JE. Comparison of vildagliptin and acarbose monotherapy in patients with Type 2 diabetes: A 24 week, double-blind, randomized trial. Diabet Med. 2008; 25(4):435-41.

[130] Wolever TM, Chiasson JL, Josse RG, Hunt JA, Palmason C, Rodger NW, Ross SA, Ryan EA, Tan MH. Small weight loss on long-term acarbose therapy with no change in dietary pattern or nutrient intake of individuals with noninsulin-dependent diabetes. Int J Obes Relat Metab Disord. 1997;21(9):756-63.

[131] Yamamoto M, Jia DM, Fukumitsu KI, Imoto I, Kihara Y, Hirohata Y, Otsuki M. Metabolic abnormalities in the genetically obese and diabetic Otsuka Long-Evans Tokushima Fatty rat can be prevented and reversed by alphaglucosidase inhibitor. Metabolism. 1999;48(3):347-54.

[132] Reaven E, Wright D, Mondon CE, Solomon R, Ho H, Reaven GM. Effect of age and diet on insulin secretion and insulin action in the rat. Diabetes. 1983;32(2):175-80.

[133] Kalant N, Stewart J, Kaplan R. Effect of diet restriction on glucose metabolism and insulin responsiveness in aging rats. Mech Ageing Dev. 1988;46(1-3):89-104.

[134] Lane MA, Ball SS, Ingram DK, Cutler RG, Engel J, Read V, Roth GS. Diet restriction in rhesus monkeys lowers fasting 
and glucose-stimulated glucoregulatory end points. Am J Physiol. 1995;268(5 Pt 1):E941-8.

[135] Harrison DE, Strong R, Allison DB, Ames BN, Astle CM, Atamna H, Fernandez E, Flurkey K, Javors MA, Nadon NL, Nelson JF, Pletcher S, Simpkins JW, Smith D, Wilkinson JE, Miller RA. Acarbose, 17- $\alpha$-estradiol, and nordihydroguaiaretic acid extend mouse lifespan preferentially in males. Aging Cell. 2014;13(2):273-82.

[136] Miller RA, Harrison DE, Astle CM, Baur JA, Boyd AR, de Cabo R, Fernandez E, Flurkey K, Javors MA, Nelson JF, Orihuela CJ, Pletcher S, Sharp ZD, Sinclair D, Starnes JW, Wilkinson JE, Nadon NL, Strong R. Rapamycin, But not resveratrol or simvastatin, extends life span of genetically heterogeneous mice. Journals Gerontol Ser A Biol Sci Med Sci. 2011;66A (2):191-201.

[137] Flurkey K, Astle CM, Harrison DE. Life extension by diet restriction and N-ACETYL-L-cysteine in genetically heterogeneous mice. Journals Gerontol Ser A Biol Sci Med Sci. 2010;65A(12):1275-84.

[138] Baron AD. Postprandial hyperglycaemia and alphaglucosidase inhibitors. Diabetes Res Clin Pract. 1998;40 (Suppl):S51-5.

[139] Hardman TC, Dubrey SW. Development and potential role of type-2 sodium-glucose transporter inhibitors for management of type 2 diabetes. Diabetes Ther. 2011;2(3):133-45.

[140] Komoroski B, Vachharajani N, Feng Y, Li L, Kornhauser D, Pfister M. Dapagliflozin, a novel, selective SGLT2 inhibitor, improved glycemic control over 2 weeks in patients with type 2 diabetes mellitus. Clin Pharmacol Ther. 2009;85(5):513-9.

[141] Basile JN. The potential of sodium glucose cotransporter 2 (SGLT2) inhibitors to reduce cardiovascular risk in patients with type 2 diabetes (T2DM). J Diabetes Complications. Elsevier Inc. 2013;27(3):280-6.

[142] Sajilata MG, Singhal RS, Kulkarni PR. Resistant Starch A Review. Compr Rev Food Sci Food Saf. 2006;5(1):1-17.

[143] Weickert MO, Pfeiffer AFH. Metabolic effects of dietary fiber consumption and prevention of diabetes. J Nutr. 2008;138(3):439-42.

[144] Montagne L, Pluske JR, Hampson DJ. A review of interactions between dietary fibre and the intestinal mucosa, and their consequences on digestive health in young non-ruminant animals. Anim Feed Sci Technol. 2003; 108(1-4):95-117.

[145] Erickson KL, Hubbard NE. Symposium: Probiotic bacteria: Implications for human health probiotic immunomodulation in health and disease 1, 2. Am Soc Nutr Sci. 2000;403-9.

[146] McCay CM, Ku CC, Woodward JC, Sehgal BS. Cellulose in the diet of rats and mice. J Nutr. 1934;8(4):435-47.

[147] Brown IL. Applications and uses of resistant starch. J AOAC Int. 87(3):727-32.

[148] Phillips J, Muir JG, Birkett A, Lu ZX, Jones GP, O'Dea $\mathrm{K}$, Young GP. Effect of resistant starch on fecal bulk and fermentation-dependent events in humans. Am J Clin Nutr. 1995;62 (1):121-30.

[149] Asp N-G, Björck I. Resistant starch. Trends Food Sci Technol. 1992;3:111-4.

[150] Han K-H, Fukushima M, Kato T, Kojima M, Ohba K, Shimada K, Sekikawa M, Nakano M. Enzyme-resistant fractions of beans lowered serum cholesterol and increased sterol excretions and hepatic mRNA levels in rats. Lipids. 2003;38(9):919-24.

[151] Raben A, Tagliabue A, Christensen NJ, Madsen J, Holst JJ, Astrup A. Resistant starch: The effect on postprandial glycemia, hormonal response, and satiety. Am J Clin Nutr. 1994;60(4):544-51.

[152] Zhou J, Keenan MJ, Fernandez-Kim SO, Pistell PJ, Ingram DK, Li B, Raggio AM, Shen L, Zhang H, McCutcheon KL, Tulley RT, Blackman MR, Keller JN, Martin RJ. Dietary resistant starch improves selected brain and behavioral functions in adult and aged rodents. Mol Nutr Food Res. 2013;57(11):2071-4

[153] Sybille T, June Z, Michael K, Roy M, Maria L. M. The intestinal microbiota in aged mice is modulated by dietary resistant starch and correlated with improvements in host responses. FEMS Microbiol Ecol. 2013;83(2):299-309.

[154] Keenan MJ, Marco ML, Ingram DK, Martin RJ. Improving healthspan via changes in gut microbiota and fermentation. Age. 2015;37(5):1-10.

[155] Langille MGI, Meehan CJ, Koenig JE, Dhanani AS, Rose RA, Howlett SE, Beiko RG. Microbial shifts in the aging mouse gut. Microbiome. 2014;2(1):1-12.

[156] Nordgaard I, Mortensen P, Langkilde A. Small intestinal malabsorption and colonic fermentation of resistant starch and resistant peptides to short-chain fatty acids. Nutrition. 1994;11(2):129-37.

[157] Charrier JA, Martin RJ, McCutcheon KL, Raggio AM, Goldsmith F, Goita M, Senevirathne RN, Brown IL, Pelkman C, Zhou J, Finley J, Durham HA, Keenan MJ. High fat diet partially attenuates fermentation responses in rats fed resistant starch from high-amylose maize. Obesity. 2013;21(11):2350-5.

[158] Vidrine K, Ye J, Martin RJ, McCutcheon KL, Raggio AM, Pelkman C, Durham HA, Zhou J, Senevirathne RN, Williams C, Greenway F, Finley J, Gao Z, Goldsmith F, Keenan MJ. Resistant starch from high amylose maize (HAM-RS2) and Dietary butyrate reduce abdominal fat by a different apparent mechanism. Obesity. 2014;22(2): 344-8.

[159] Văserman AM, Koliada AK, Koshel' NM, Simonenko AV, Pasiukova EG. Effect of the histone deacetylase inhibitor sodium butyrate on the viability and life span in Drosophila melanogaster. Adv Gerontol. 2012;25(1):126-31.

[160] Maslowski KM, Vieira AT, Ng A, Kranich J, Sierro F, Yu D, Schilter HC, Rolph MS, Mackay F, Artis D, Xavier RJ, Teixeira MM, Mackay CR. Regulation of inflammatory responses by gut microbiota and chemoattractant receptor GPR43. Nature. 2009;461(7268):1282-6.

[161] Maslowski KM, Mackay CR. Diet, gut microbiota and immune responses. Nat Immunol. 2011;12(1):5-9.

[162] Chung HY, Cesari M, Anton S, Marzetti E, Giovannini S, Seo AY, Carter C, Yu BP, Leeuwenburgh C. Molecular inflammation: Underpinnings of aging and age-related diseases. Ageing Res Rev. 2009;8(1):18-30.

[163] Dandona P. Inflammation: The link between insulin resistance, obesity and diabetes. Trends Immunol. 2004;25(1): 4-7.

[164] Cummings JH, Macfarlane GT. The control and consequences of bacterial fermentation in the human colon. J Appl Bacteriol. 1991;70(6):443-59.

[165] Pomare EW, Branch WJ, Cummings JH. Carbohydrate fermentation in the human colon and its relation to 
acetate concentrations in venous blood. J Clin Invest. 1985;75(5):1448-54.

[166] Su B, Liu H, Li J, Sunli Y, Liu B, Liu D, Zhang P, Meng $X$. Acarbose treatment affects the serum levels of inflammatory cytokines and the gut content of bifidobacteria in Chinese patients with type 2 diabetes mellitus. J Diabetes. (Wiley Online Library) 2015;7(5):729-39.

[167] Maruhama Y, Nagasaki A, Kanazawa Y, Hirakawa H, Goto Y, Nishiyama H, Kishimoto Y, Shimoyama T. Effects of a glucoside-hydrolase inhibitor (bay g 5421) on serum lipids, lipoproteins and bile acids, fecal fat and bacterial flora, and intestinal gas production in hyperlipidemic patients. Tohoku J Exp Med. 1980;132(4):453-62.

[168] Cabreiro F, Au C, Leung K-Y, Vergara-Irigaray N, Cochemé HM, Noori T, Weinkove D, Schuster E, Greene NDE, Gems D. Metformin retards aging in C. elegans by altering microbial folate and methionine metabolism. Cell. 2013;153(1):228-39.

[169] Forslund K, Hildebrand F, Nielsen T, Falony G, Le Chatelier E, Sunagawa S, Prifti E, Vieira-Silva S, Gudmundsdottir V, Krogh Pedersen H, Arumugam M, Kristiansen K, Yvonne Voigt A, Vestergaard H, Hercog R, Igor Costea P, Roat Kultima J, Li J, Jørgensen T, Levenez F, Dore J, Bjørn Nielsen H, Brunak S, Raes J, Hansen T, Wang J, Dusko Ehrlich S, Bork P, Pedersen O, Pedersen O. Disentangling type 2 diabetes and metformin treatment signatures in the human gut microbiota. Nature. (Nature Research) 2015;528(7581):262-6.

[170] Buse JB, DeFronzo RA, Rosenstock J, Kim T, Burns C, Skare S, Baron A, Fineman M. The primary glucoselowering effect of metformin resides in the gut, not the circulation: Results from short-term pharmacokinetic and 12-week dose-ranging studies. Diabetes Care. American Diabetes Association. 2016;39(2):198-205.

[171] Getek M, Czech N, Muc-Wierzgon M, GrochowskaNiedworok E, Kokot T, Nowakowska-Zajdel E. The active role of leguminous plant components in type 2 diabetes. Evidence-Based Complement Altern Med. Hindawi Publishing Corporation. 2014;2014:1-12.

[172] Morikawa T, Chaipech S, Matsuda H, Hamao M, Umeda Y, Sato H, Tamura H, Kon'i H, Ninomiya K, Yoshikawa M, Pongpiriyadacha Y, Hayakawa T, Muraoka O. Antidiabetogenic oligostilbenoids and 3-ethyl4-phenyl-3,4-dihydroisocoumarins from the bark of Shorea roxburghii. Bioorg Med Chem. 2012;20(2):832-40.

[173] Jaiswal N, Bhatia V, Srivastava SP, Srivastava AK, Tamrakar AK. Antidiabetic effect of Eclipta alba associated with the inhibition of alpha-glucosidase and aldose reductase. Nat Prod Res. 2012;26(24):2363-7.

[174] Yao Y, Cheng X, Ren G. $\alpha$-Glucosidase inhibitory activity of protein-rich extracts from extruded adzuki bean in diabetic KK-Ay mice. Food Funct. 2014;5(5):966.

[175] Itoh T, Kita N, Kurokawa Y, Kobayashi M, Horio F, Furuichi Y. Suppressive effect of a hot water extract of adzuki beans (vigna angularis) on hyperglycemia after sucrose loading in mice and diabetic rats. Biosci Biotechnol Biochem. 2004;68(12):2421-6.

[176] Shori AB. Screening of antidiabetic and antioxidant activities of medicinal plants. J Integr Med. 2015;13(5):297-305.

[177] Islam MN, Ishita IJ, Jung HA, Choi JS. Vicenin 2 isolated from Artemisia capillaris exhibited potent anti-glycation properties. Food Chem Toxicol. 2014;69:55-62.
[178] Zhang B, Deng Z, Ramdath DD, Tang Y, Chen PX, Liu R, Liu Q, Tsao R. Phenolic profiles of 20 Canadian lentil cultivars and their contribution to antioxidant activity and inhibitory effects on $\alpha$-glucosidase and pancreatic lipase. Food Chem. 2015;172:862-72.

[179] Adisakwattana S, Lerdsuwankij O, Poputtachai U, Minipun A, Suparpprom C. Inhibitory activity of cinnamon bark species and their combination effect with acarbose against intestinal $\alpha$-glucosidase and pancreatic $\alpha$-amylase. Plant Foods Hum Nutr. 2011;66(2):143-8.

[180] Mohamed Sham Shihabudeen H, Hansi Priscilla D, Thirumurugan K. Cinnamon extract inhibits $\alpha$-glucosidase activity and dampens postprandial glucose excursion in diabetic rats. Nutr Metab. 2011;8(1):46.

[181] Medagama AB. The glycaemic outcomes of Cinnamon, a review of the experimental evidence and clinical trials. Nutr J. 2015;14(1):108.

[182] Willcox BJ, Willcox DC, Todoriki H, Fujiyoshi A, Yano K, He Q, Curb JD, Suzuki M. Caloric restriction, the traditional Okinawan diet, and healthy aging: The diet of the world's longest-lived people and its potential impact on morbidity and life span. Ann N Y Acad Sci. 2007;1114:434-55.

[183] Sho H. History and characteristics of Okinawan longevity food. Asia Pac J Clin Nutr. 2001;10(2):159-64.

[184] Bovell-Benjamin AC. Sweet potato: A review of its past, present, and future role in human nutrition. Adv Food Nutr Res. 2007;52:1-59.

[185] Tiwari AK, Rao JM. Diabetic mellitus and multiple therapeutic approaches of phytochemicals: Present status and future prospects. Curr Sci. 2002;83(1):30-7.

[186] Kim JS, Kwon CS, Son KH. Inhibition of alpha-glucosidase and amylase by luteolin, a flavonoid. Biosci Biotechnol Biochem. 2000;64(11):2458-61.

[187] Matsui T, Ueda T, Oki T, Sugita K, Terahara N, Matsumoto K. $\alpha$-Glucosidase inhibitory action of natural acylated anthocyanins. 1. Survey of natural pigments with potent inhibitory activity. J Agric Food Chem. 2001;49(4): 1948-51.

[188] Du Z, Liu R, Shao W, Mao X, Ma L, Gu L, Huang Z, Chan ASC. $\alpha$-Glucosidase inhibition of natural curcuminoids and curcumin analogs. Eur J Med Chem. 2006;41(2):213-8.

[189] Matecic M, Smith DL, Pan X, Maqani N, Bekiranov S, Boeke JD, Smith JS. A Microarray-based genetic screen for yeast chronological aging factors. Kim SK, editor. PLoS Genet. 2010;6(4):e1000921.

[190] Smith DL Jr, McClure JM, Matecic M, Smith JS. Calorie restriction extends the chronological lifespan of Saccharomyces cerevisiae independently of the Sirtuins. Aging Cell. 2007;6(5):649-62.

[191] Schulz TJ, Zarse K, Voigt A, Urban N, Birringer M, Ristow $M$. Glucose restriction extends caenorhabditis elegans life span by inducing mitochondrial respiration and increasing oxidative stress. Cell Metab. 2007;6(4):280-93.

[192] Masoro EJ, Mccarter RJM, Katz MS, Mcmahan CA. Dietary restriction alters characteristics of glucose fuel use. J Gerontol. 1992;47(6):202-8.

[193] Masoro EJ. Possible mechanisms underlying the antiaging actions of caloric restriction. Toxicol Pathol. 1996; 24(6):738-41.

[194] Miller RA, Buehner G, Chang Y, Harper JM, Sigler $\mathrm{R}$, Smith-Wheelock M. Methionine-deficient diet extends mouse lifespan, slows immune and lens aging, alters 
glucose, T4, IGF-I and insulin levels, and increases hepatocyte MIF levels and stress resistance. Aging Cell. 2005;4(3):119-25.

[195] Malloy VL, Krajcik RA, Bailey SJ, Hristopoulos G, Plummer JD, Orentreich N. Methionine restriction decreases visceral fat mass and preserves insulin action in aging male Fischer 344 rats independent of energy restriction. Aging Cell. 2006;5(4):305-14.

[196] Anson RM, Guo Z, de Cabo R, Iyun T, Rios M, Hagepanos A, Ingram DK, Lane MA, Mattson MP. Intermittent fasting dissociates beneficial effects of dietary restriction on glucose metabolism and neuronal resistance to injury from calorie intake. Proc Natl Acad Sci. 2003;100(10): 6216-20.

[197] Varady KA, Hellerstein MK. Alternate-day fasting and chronic disease prevention: A review of human and animal trials. Am J Clin Nutr. 2007;86(1):7-13.

[198] Borg KE, Brown-Borg HM, Bartke A. Assessment of the primary adrenal cortical and pancreatic hormone basal levels in relation to plasma glucose and age in the unstressed ames dwarf mouse. Exp Biol Med. 1995;210(2):126-33.

[199] Bartke A, Brown-Borg H. Life extension in the dwarf mouse. Curr Top Dev Biol. 2004;63:189-225.

[200] Hsieh C-C, DeFord JH, Flurkey K, Harrison DE, Papaconstantinou J. Effects of the Pit1 mutation on the insulin signaling pathway: Implications on the longevity of the long-lived Snell dwarf mouse. Mech Ageing Dev. 2002;123(9):1245-55.

[201] Hauck SJ, Hunter WS, Danilovich N, Kopchick JJ, Bartke A. Reduced levels of thyroid hormones, insulin, and glucose, and lower body core temperature in the growth hormone receptor/binding protein knockout mouse. Exp Biol Med. 2001;226(6):552-8.

[202] Blüher M, Michael MD, Peroni OD, Ueki K, Carter N, Kahn BB, Kahn CR. Adipose tissue selective insulin receptor knockout protects against obesity and obesity-related glucose intolerance. Dev Cell. 2002;3(1):25-38.
[203] Yan L, Vatner DE, O'Connor JP, Ivessa A, Ge H, Chen W, Hirotani S, Ishikawa Y, Sadoshima J, Vatner SF. Type 5 adenylyl cyclase disruption increases longevity and protects against stress. Cell. 2007;130(2):247-58.

[204] Yan L, Park JY, Dillinger J-G, De Lorenzo MS, Yuan C, Lai L, Wang C, Ho D, Tian B, Stanley WC, Auwerx J, Vatner DE, Vatner SF. Common mechanisms for calorie restriction and adenylyl cyclase type 5 knockout models of longevity. Aging Cell. 2012;11(6):1110-20.

[205] Vatner SF, Vatner DE, Yan L. Models of longevity (Calorie restriction and AC5 KO): Result of three bad hypotheses. Aging. 2012;4(10):662-3.

[206] Pyo J-O, Yoo S-M, Ahn H-H, Nah J, Hong S-H, Kam T-I, Jung S, Jung Y-K. Overexpression of Atg5 in mice activates autophagy and extends lifespan. Nat Commun. 2013;4:2300.

[207] Zhang Y, Xie Y, Berglund ED, Coate KC, He TT, Katafuchi T, Xiao G, Potthoff MJ, Wei W, Wan Y, Yu RT, Evans RM, Kliewer SA, Mangelsdorf DJ. The starvation hormone, fibroblast growth factor-21, extends lifespan in mice. Elife. eLife Sciences Publications Limited. 2012;1:e00065.

[208] Miskin R, Masos T. Transgenic mice overexpressing urokinase-type plasminogen activator in the brain exhibit reduced food consumption, body weight and size, and increased longevity. Journals Gerontol Ser A Biol Sci Med Sci. 1997;52A(2):B118-24.

[209] Selman C, Tullet JMA, Wieser D, Irvine E, Lingard SJ, Choudhury AI, Claret M, Al-Qassab H, Carmignac D, Ramadani F, Woods A, Robinson ICA, Schuster E, Batterham RL, Kozma SC, Thomas G, Carling D, Okkenhaug K, Thornton JM, Partridge L, Gems D, Withers DJ. Ribosomal protein S6 kinase 1 signaling regulates mammalian life span. Science. 2009;326(5949):140-4.

[210] Enns LC, Morton JF, Treuting PR, Emond MJ, Wolf NS, Dai D-F, McKnight GS, Rabinovitch PS, Ladiges WC. Disruption of protein kinase A in mice enhances healthy aging. PLoS One. Public Library of Science. 2009;4(6):e5963. 